\title{
Cytology and Taxonomic Description of Two Brachiarias (Congograss and Tannergrass)'
}

\author{
A. Sotomayor-Rios, S. C. Schank, and R. Woodbury ${ }^{2}$
}

\section{INTRODUCTION}

The grass species belonging to the genus Brachiaria have proven to be excellent replacements for Pangolagrass in Surinam where a severe infestation of Pangola stunt virus occurs (7)..$^{3}$ The Brachiaria grasses are well adapted to the Tropics and some of them should be considered for more extensive research and breeding work because they apparently are not susceptible to the stunt virus. Signalgrass (Brachiaria brizantha Stapf.) was reported early in 1960 to be an outstanding introduction in Puerto Rico (12). Further studies on grazing, palatability and digestibility of this grass confirmed its potentialities and value $(1,10)$.

The popularity of Signalgrass is spreading rapidly in Puerto Rico, because of its resistance to insect attack, its high-yield potential, and its aggressiveness. It is highly resistant to trampling because it forms a thick mat which allows rapid recovery from grazing (10).

The introduction of a large number of grasses in years past by the Plant Breeding Department of this Station has broadened the genetic potentialities of the genus Brachiaria. Among these introductions, Congograss (Brachiaria ruziziensis, Germain C. Evrard), and Tannergrass (Brachiaria $s p$.) have shown desirable agronomic characters in experimental plots in various locations.

A study was initiated at the Corozal Substation to determine the chromosome number and to investigate other cytological aspects of Congograss and Tannergrass to obtain basic information for use in developing a breeding program within the genus Brachiaria. One of the prime considerations in hybridization effort is the viability of pollen and growth of pollen tubes in desired crosses. Goss (5) emphasized the many problems associated with pollen studies in a recent Botanical Review. He states: ". . . we do not even have good media or environmental conditions for the culture of wheat and

1 Joint contribution from the Agricultural Experiment Station, Mayagüez Campus, University of Puerto Rico, Río Piedras, P.R., and the Florida Agricultural Experiment Station, Gainesville, Florida 32601.

2 The first and third authors are: Associate Plant Breeder in Charge, Corozal Substation, and Taxonomist, Agricultural Experiment Station, Mayagüez Campus, University of Puerto Rico, respectively. The secund author is Associate Agronomist, Institute of Food and Agricultural Sciences, University of Florida, Gainesville. The authors acknowledge Mr. F. Roena for his excellent line drawings.

${ }^{3}$ Italic numbers in parentheses refer to Literature Cited, p. 400. 
corn pollen in vitro with success that anywhere near approaches their germination in vivo." It is well known that the trinucleate pollen from the grass family is notoriously hard to germinate in vitro.

This paper reports some successful investigations on both in vitro and in vivo pollen germination and includes a taxonomic description of the two grasses studied.

\section{MATERIALS AND METHODS}

Seed of Congograss (B. ruziziensis), Puerto Rico P.I. No. 5366, was introduced to this Station on March, 1962 as USDA P.I. No. 247404. The original seeds came from Venezuela via the United States and then to the Plant Breeding Department of this Station. This grass is native to the Ruzizi plains in the Congo, according to Blydenstein (2). Tannergrass (Brachiaria sp.), Puerto Rico P.I. No. 6451, was introduced to Puerto Rico in 1964 as part of the Oakes Collection, USDA P.I. No. 299499, (8), but the material did not survive the quarantine observation period. ${ }^{4}$ It was reintroduced from the Range Cattle Station, Ona, Florida, on June 1966 by Dr. J. Vélez-Fortuño.

Material for these taxonomic and cytological studies was obtained from field plots at the Corozal Substation of the Agricultural Experiment Station.

Inflorescences were killed and fixed in a modified Carnoy's solution consisting of absolute ethanol, glacial acetic acid and chloroform in a 10:3:3 proportion. Chromosomes were stained with aceto-orcein, and pollen with aniline blue in lactophenol.

Germination of pollen on artificial media followed the basic procedure reported by Wallace and Karbassi (13) with modifications. Substrate used in this study was prepared by adding $100 \mathrm{ml}$. of distilled water to $12 \mathrm{~g}$. of sucrose, $3 \mathrm{~g}$. of agar, $20 \mathrm{mg}$. of calcium nitrate and $20 \mathrm{mg}$. boric acid. Pollen to be germinated was from newly emerged anthers after complete elongation of the filaments had taken place. At the time of dehiscence the spikelets were tapped and pollen was allowed to fall on a $20 \mathrm{~mm} .{ }^{2}$ section of agar. At a temperature of $23.5^{\circ}$ to $25.0^{\circ} \mathrm{C}$., pollen germination was allowed to proceed for 2 hours, then killing and fixing of pollen tubes was accomplished with a 1:1 mixture of absolute ethanol and glacial acetic acid. Fifty measurements of pollen tubes were made at random from the two species.

The in vivo technique used involved stigmas from hand-emasculated spikelets placed in an upright condition on 3-percent agar media in a petri dish. All stigmas were hand-pollinated and incubation was allowed for 3 and 6 hours. The staining procedure of Datta and Naug (4) was employed

4 Written communication to the senior author by Dr. J. Vélez-Fortuño, Head, Department of Plant Breeding, Agricultural Experiment Station, Río Piedras, P.R. 
in scoring pollen tubes, and the percentage of in vivo pollen germination was calculated.

\section{RESULTS AND DISCUSSION}

Cytological data on the chromosome numbers, pollen stainability, and pollen germinability is presented in table 1. Additional information on megasporogenesis and embryo sac development in these lines was reported previously (11).

Chromosome numbers of Congograss and Tannergrass were found to be $2 n=18$ and $2 n=36$, respectively, from observations made at metaphase I (figs. 1, A, 1, B). Meiosis appeared normal in Congograss, whereas lagging univalents were observed in Tannergrass (fig. $1, \mathrm{C}$ ).

The somewhat lower pollen stainability encountered in Tannergrass may

TABLe 1.-Summary of cylological data on two Brachiaria species

\begin{tabular}{l|c|c}
\hline \multicolumn{1}{c|}{ Item } & $\begin{array}{c}\text { B. ruziziensis (Congograss) } \\
\text { P.R. P.I. 5366, USDA 247404 }\end{array}$ & $\begin{array}{c}\text { B. sp. (Tannergrass) P.R. P.I. 6451, } \\
\text { USDA 299499 }\end{array}$ \\
\cline { 2 - 3 } Chromosome number & $\begin{array}{c}2 n=18 \\
\text { (regular meiosis) } \\
88.0\end{array}$ & $\begin{array}{c}2 n=36 \\
\text { (laggards observed T1) } \\
67.0\end{array}$ \\
$\begin{array}{l}\text { Pollen stainability (per } \\
\text { cent) }\end{array}$ & 39.3 & 44.4 \\
$\begin{array}{l}\text { Pollen germination in vivo } \\
\text { (per cent) }\end{array}$ & 11.3 & 9.0 \\
$\begin{array}{l}\text { Pollen germination on } \\
\text { artificial media (per cent) }\end{array}$ & $275 \mu$ & $176 \mu$ \\
$\begin{array}{l}\text { Pollen tube length on arti- } \\
\text { ficial media }\end{array}$ & $4.7 \mathrm{~mm}$. & $3.9 \mathrm{~mm}$. \\
$\begin{array}{l}\text { Length of styles } \\
\text { Seed set at Corozal }\end{array}$ & 0 & 0 \\
\hline
\end{tabular}

be due to the laggard chromosomes which were observed in 11 percent of the microsporocytes. Over 150 microsporocytes were scored at $T I$, in each species. Congograss, however, had entirely regular meiosis. Lack of seed set in Congograss under the ecological conditions of the Corozal Substation cannot be explained because this species is known to produce viable seed in other tropical countries.

The successful germination of pollen on artificial media and in vivo, (figs. 1, D, 1, E, 1, F, 1, G) offers the plant breeder more precise methods of measuring pollen viability. Utilizing the in vivo method, higher germination percentages were obtained as compared to the artificial media. It was found that, self-pollinated Tannergrass produced 44.4 percent pollen with tubes, and Congograss on selfing produced 39.3 percent pollen with tubes. When Congograss pollen was placed on the styles of Tannergrass, 64.8 percent of the grains produced tubes. The in vivo test is believed therefore to be 


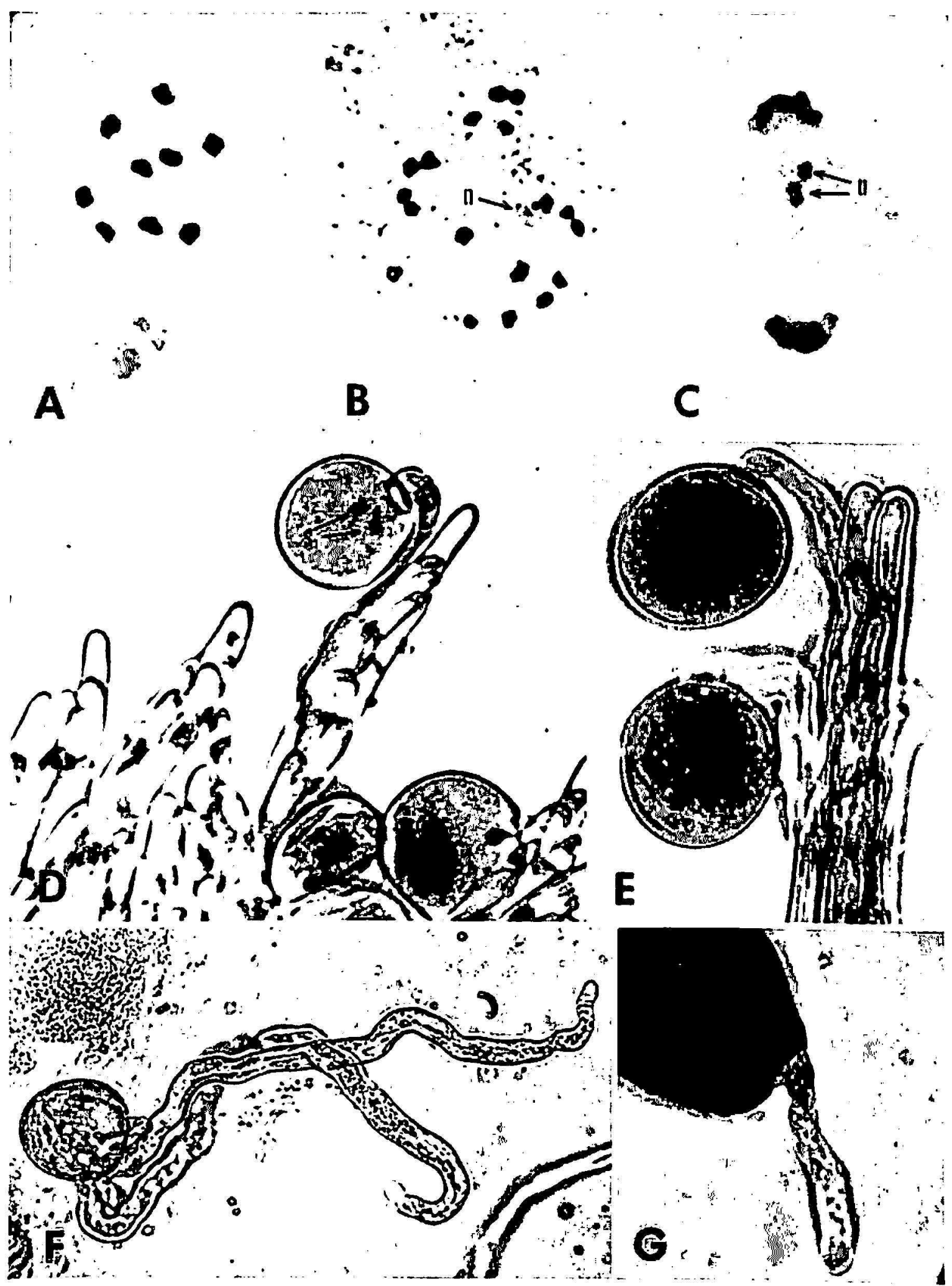

FIG. 1.-Cytology of Congograss and Tannergrass. Microsporocytes of Congograss, $A, \times 1450$, and Tannergrass $B, \times 1100$, at diakinesis. Arrow indicates nucleolus. Lagging univalents, $C$, in Tannergrass, $\times 1500$. Two sperm nuclei in a microspore of Congograss, D, germinating in vivo on Tannergrass, $\times 500$. Pollen germination, $\mathrm{E}$, upon selfing Tannergrass, $\times 600$. Germination on artificial media of Tannergrass, F, and Congograss, G. 


$$
\text { WE }
$$


more reliable as a test of viability. On the artificial media, pollen germination varied from 3 to 23 percent, with tubes ranging from 50 to $700 \mu$ in length. From a single pore of Tannergrass pollen, one double tube was observed (fig. 1, F), a finding in accordance with Pfahler (9) who also reported this condition in Zea mays.

The in vivo technique also should be of interest to plant breeders who desire to study pollen incompatibility. Pollen from the same plant, or from a different species, can be placed easily on the stigma, allowed to germinate, and then analyzed microscopically for presence or absence of tubes.

It is well known that most species of Brachiaria in cultivation are quite variable in morphological and agronomical characteristics. Questionable identifications thus are frequent. Taxonomic descriptions of the two species are presented below to prevent future misinterpretation.

\section{DESCRIPTION OF TANNERGRASS}

Tannergrass is a vigorous stoloniferious perennial (fig. 2) producing a dense cover to 1 or more meters high at the Corozal Substation. This glabrous plant produces divergent leaves which gradually become shorter towards the base and apex of the stem. The sheath at first is clasping but becomes less or not at all clasping upon maturation. It is glabrous except for the scabrous to short ciliate margin. The ligule is reduced to a ring of close ciliate hairs to one $\mathrm{mm}$. long. The blade is narrowly lanceolate with a truncated base and acuminate apex. The margin is finely serrate with stiff hairs. It is 5 to $12 \mathrm{~cm}$. long by 1 to $1.6 \mathrm{~cm}$. wide.

The inflorescence (fig. $3, \mathrm{~A}$ ) is an elongated panicle produced by eight to ten spike-like, racemes 2 to $5.5 \mathrm{~cm}$. long. The lower-most racemes are much longer than the abortive upper-most ones giving the panicle a conelike shape. The rachis of the raceme is rather narrowly winged, 1.0 to 1.5 $\mathrm{mm}$. wide, and flat on the back. It is glabrous except for base and peduncle which are densely pubescent with short hairs and a few ciliate hairs. The margin of the rachis is finely serrate by projecting hairs. The single spikelets are attached in two close rows to the ribbed rachis by a short $(1 \mathrm{~mm}$.) finely pubescent pedicel which is dilated above. The dilated part of the pedicel is beset with from one to three long stiff, cilia $1 \mathrm{~mm}$. or more long.

The glabrous spikelets (figs. 3, B, C, and D) are elliptic-lanceolate to oblanceolate in outline and 3.5 to $3.8 \mathrm{~mm}$. long except for the abortive ones often seen at the base, or sometimes at the apex of the raceme. The lower glume, as well as the upper glume and male lemma, is somewhat rose-purple. It is one-third the length of the spikelet, 5-nerved and with an acute apex. The second glume is as long as the spikelet, 9-nerved and anastomosing above the middle. The apex is acute to short acuminate. The lemma of the male floret is similar to the second glume but 5- to 7-nerved. It has three 
stamens with large purple anthers. The fertile, or female lemma (fig. 3, E) is durate, slightly shorter than the spikelet, obtuse and horizontally, rugosely ribbed. The palea is similar to the lemma but vertically, rugosely ribbed.

The description of Tannergrass is similar to that of $B$. arrecta (Hack.)
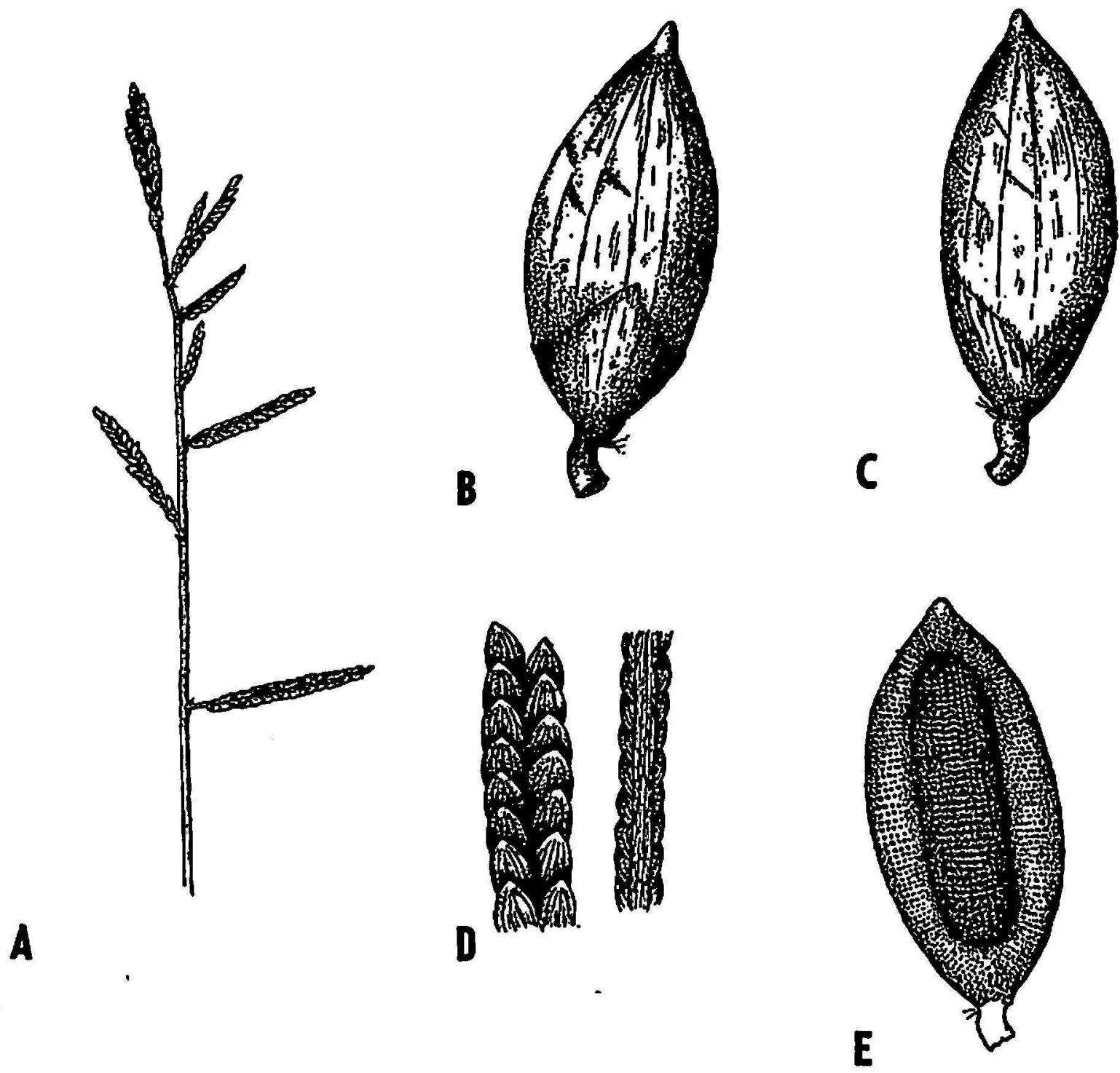

Fra. 3.-Tannergrass. A, Panicle, $X 1 ; B$ and $C$, spikelet, front and back view, $\times 20$; $D$, lower and upper view of raceme, $X 4$ and $\times 2$; and, $E$, spikelet showing inner lemma and palea, $\times 20$.

Stent as described by Chippindall in the grasses and pastures of South Africa (3), except for the slightly shorter lower lemma with an obtuse apex not characteristic of $B$. arrecta. A weedy grass species similar to Tannergrass occurs in Florida and other low sandy open ground areas. This weedy species has been described by Hitchcock ( 6 ) as $B$. platyphylla. 


\section{DESCRIPTION OF CONGOGRASS}

Congograss is a vigorous, stoloniferous perennial (fig. 4) with erect to decumbent stems which root at the base. In cultivation it forms a dense growth of 1 or more meters in height. This hairy plant produces leaves with

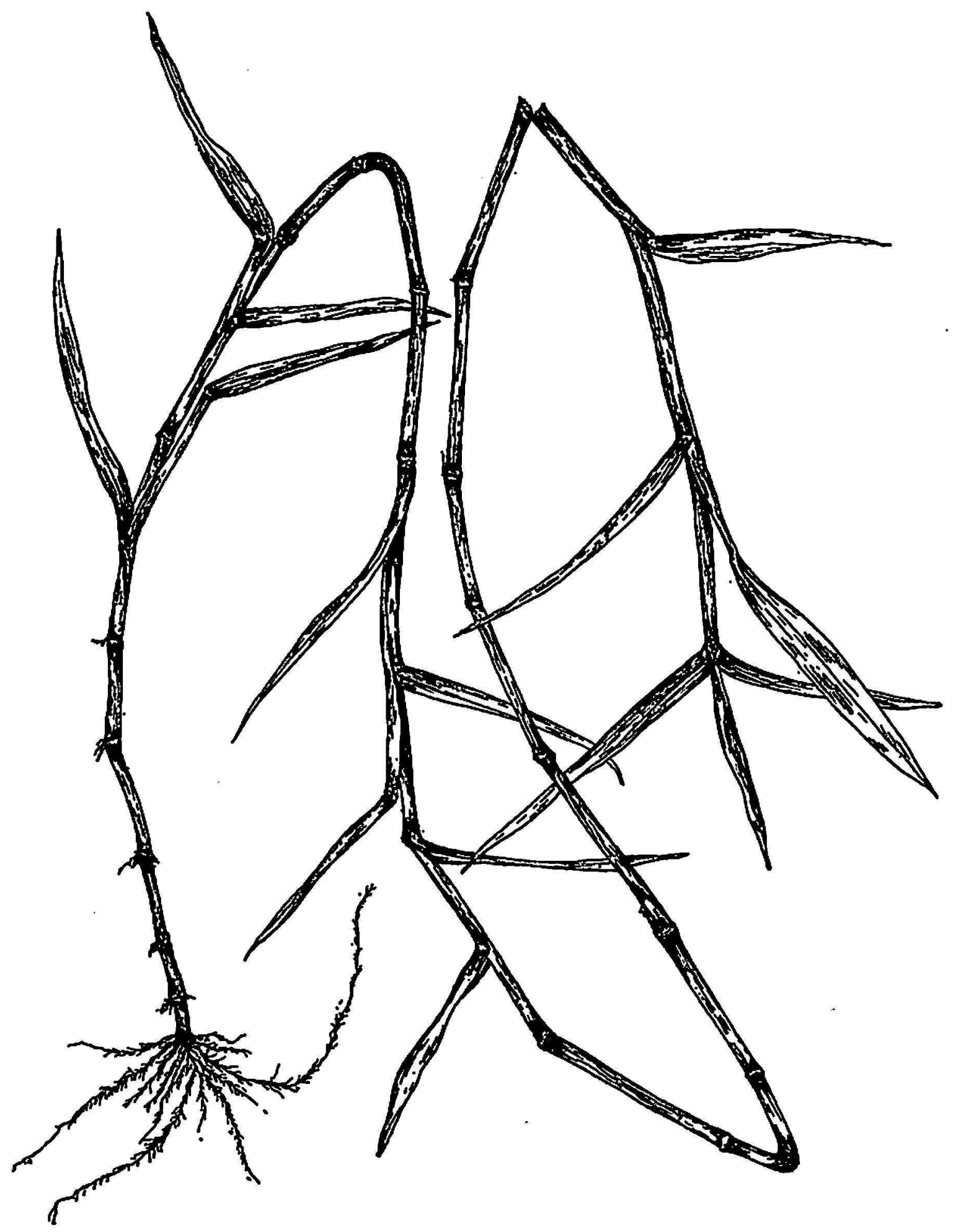

Fre. 4.-Congograss, plant, $\times 1$. 
lower sheaths shorter than the blade and upper sheaths longer than the blade. Sheaths are 7 to $16 \mathrm{~cm}$. long, bulbous villose. Blades are 6 to $12 \mathrm{~cm}$. long (rarely to $25 \mathrm{~cm}$.) by 8 to $17 \mathrm{~mm}$. wide, bulbous villose on both surfaces. Leaf margins are sclerose and serrate hirsutulose, with pubescence becom-
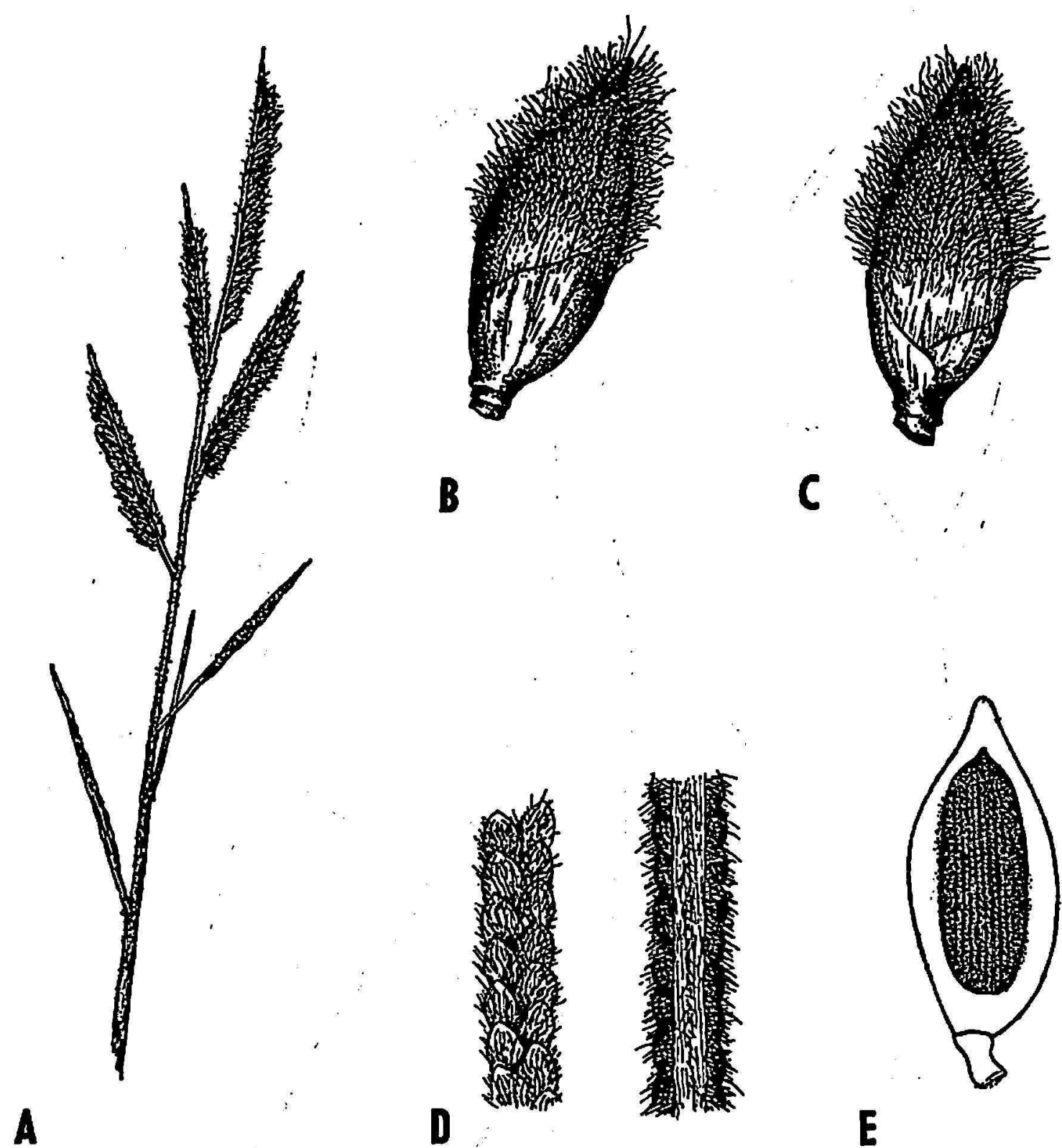

B
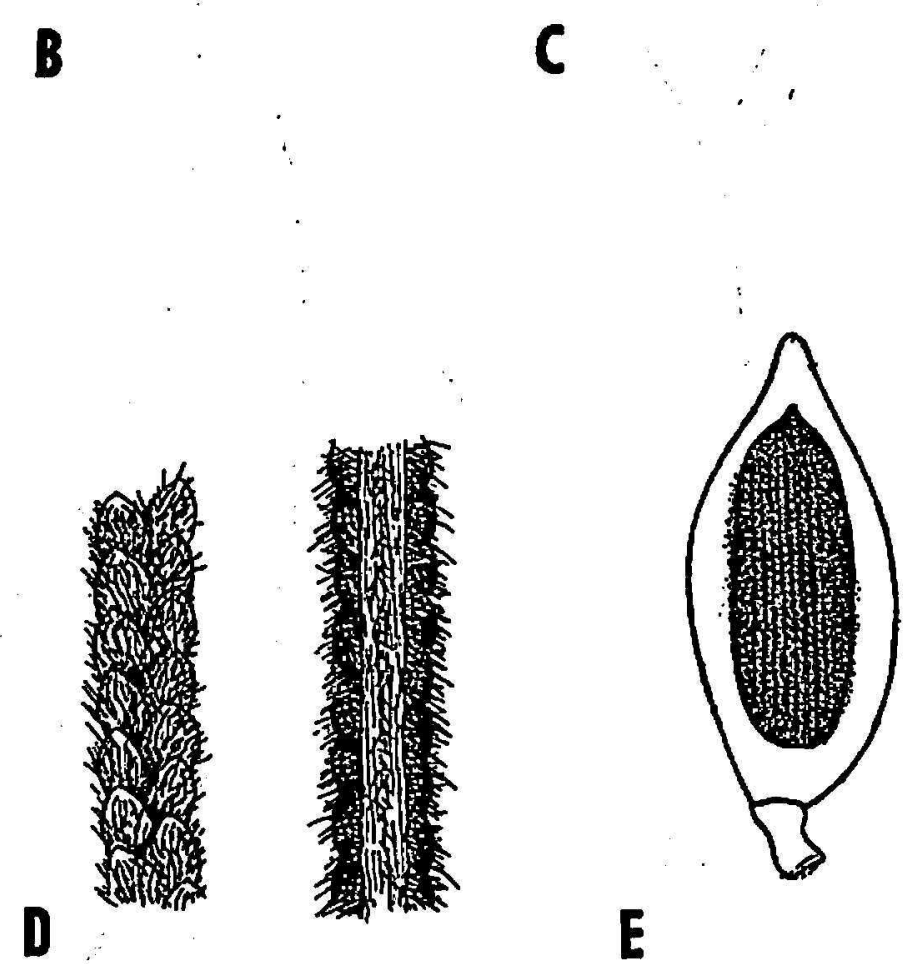

E

FTG. 5.-Congograss. A, panicle, $X 1 ; B$ and $C$, spikelet, front and back view, $X 18$; $D$, portion of raceme lower and upper view, $X 3$ and $X 2$; and $E$, spikelet showing inner lemma and palea, $X 18$.

ing denser at the junction of sheath and blade. Ligule consists of a dense ring of ciliate hairs to $1 \mathrm{~mm}$. long. Blades are truncate at the base and long acuminate at the apex.

The base of the inflorescence is partially enclosed in the upper leaf sheath, and the panicle (fig. $5, \mathrm{~A}$ ) is up to $20 \mathrm{~cm}$. long and $4 \mathrm{~cm}$. wide. Branches or 
racemes number 7 to 12 and are 5 to $7 \mathrm{~cm}$. long. The rachis prominently winged ( 2 to $3.2 \mathrm{~mm}$. wide), finely villose on back and ciliate villose on the margin (base of cilia bulbous). The inner surface of rachis has densely short hairs along the main axis and the lower portion of pedicel:

Spikelets (figs. 5, B, C, and D) are subopposite, 4 to $4.5 \mathrm{~mm}$. long. Pedicels are up to $4 \mathrm{~mm}$. in length including the glabrous constriction at the base of spikelet. One-half to two-thirds of the pedicel is adnate to the rachis. The spikelet is oblong-elliptic to oblanceolate and its base abruptly constricted ( $0.5 \mathrm{~mm}$. long). The lower (first) glume is half the length of the spikelet with 11 to 13 ribs which anastomose at the apex to form 9 irregular apical margin veins. The second glume is as long as the spikelet, abruptly acute to mucronate, bulbous ciliate in the upper two thirds and is 7-ribbed. There is a $0.5 \mathrm{~mm}$. separation between the first and second glumes.

The male lemma is like the inner glume but is 5-ribbed and slightly less ciliate. The fertile lemma and palea are durate and faintly rugosecancellate; apex mucronate in herbarium material and acuminate in living material (fig. 5, E). The stamens are three in number and yellowish in color. The ovary has two stigmas which are deep purple. Frequently the lowermost spikelets and occasionally a few at the apex are abortive.

\section{SUMMARY}

The chromosome number and microsporogenesis of two plant introductions, Congograss (Brachiaria ruziziensis) and Tannergrass (Brachiaria sp.), were determined to evaluate the possibility of utilizing these two grasses in a breeding program. Two techniques of pollen germination were utilized as a means to study pollen viability. Although germination on artificial media was successful, the in vivo technique provided a more reliable test of viability. Germination of pollen was examined in vivo with percent tube formation scored under both selfing and crossing. Both Tannergrass and Congograss were described taxonomically.

The chromosome numbers of Congograss and Tannergrass were found to be $2 n=18$ and $2 n=36$ respectively. From observations made at metaphase I, meiosis appeared normal in Congograss and no laggards were observed. In Tannergrass, lagging univalents were observed which could account for the low pollen stainability obtained.

The pollen germination on artificial media and the in vivo techniques undoubtedly can be applied to other genera.

\section{RESUMEN}

Se hizo un estudio sobre el número de cromosomas y la microsporogénesis en las yerbas Congo (Brachiaria ruziziensis) y Tanner (Brachiaria sp.), con el propósito de evaluar la posibilidad de utilizarlas en un programa de 
hibridación. Se utilizaron dos técnicas de germinación como medios para estudiar la viabilidad del polen. Aunque la germinación en un medio artificial resultó exitoso, la técnica in vivo fue la forma más confiable para medir la viabilidad del polen. Mediante la técnica in vivo, se estudió el polen y se determinó el porcentaje de formación de tubos tanto en cruces como en casos de autofecundación. Ambas yerbas se describieron taxonómicamente.

Se encontró que el número de cromosomas de las yerbas Congo y Tanner era $2 n=18$ y $2 n=36$, respectivamente. A base de las observaciones hechas durante la metafase I, la miosis pareció ser normal en la yerba Congo, pues no se observaron univalentes retardados. En la yerba Tanner se observaron univalentes retardados, lo que podría explicar el porcentaje bajo de polen teñible que se obtuvo.

La germinación del polen en un medio artificial y las técnicas in vivo, indudablemente pueden aplicarse a otros géneros.

\section{LITERATURE CITED}

1. Arroyo-Aguilu, J. A., and Rivera-Brenes, L., Digestibility studies on Napier (Merker) grass (Pennisetum purpureum Sch.), Giant pangols (Digitaria valida Stent), and Signalgrass (Brachiaria brizantha Stapf.),J. Agr. Univ. P.R. 45 (3): 148-50, 1961.

2. Blydenstein, J., Root and leaf development of Brachiaria ruziziensis seedlings, Trop. Agr. 44 (4): 1967.

3. Chippindall, L. K. A., The Grasses and Pastures of South Africa. Part 1, A guide to the identification of grasses in South Africa, Central News Agency, Parow, C. P., 771 pp., 1955.

4. Datta, P. C., and Naug, A., Staining pollen tubes in style; cotton blue versus carmine for general use, Stain Technol. 42 (2): 81-5, 1967.

5. Goss, J. A., Development, physiology, and biochemistry of corn and wheat pollen, Bot. Rev. 34 (3): 333-58, 1968.

6. Hitchcock, A. S., Manual of the Grasses of the United States, Misc. Pub. No. 200, USDA, Washington, D.C., 1051 pp., 1950.

7. Hunkar, A. E. S., Three Brachiaria species adapted to well drained soils, Bull. 82, Agr. Exp. Sta., Paramaribo, Surinam, 1963.

8. Oakes, A. J., Digitaria collection from South Africa, Trop. Agr. 48: 323-31, 1965.

9. Pfahler, P. L., In vitro germination of rye (Secale cerale L.) pollen, Crop Sci. 5 (6): Nov.-Dec., 1965.

10. Rivera-Brenes, L., Rodríguez-Cabrera, A., and Cestero, H., Comparison of Giant Pangola, Signalgrass, and Common Pangola as pasture crops in the Mountain Region of Puerto Rico, J. Agr. Univ. P.R. 51 (3): 193-200, 1967.

11. Schank, S. C., and Sotomayor-Ríos, A. Cytological studies on Brachiaria species, Soil Crop Sci. Proc. Fla. 29: [In Press], 1968.

12. Sotomayor-Ríos, A., Velez-Fortuno, J., Woodbury, R., Schertz, K. F., and Sierra-Bracero, A., Description and cytology of a form of Signalgrass (Brachiaria brizantha Stapf.) and its agronomic behavior compared to Guineagrass (Panicum maximum Jack.), J, Agr. Univ. P.R. 44 (4): 208-20, 1960.

13. Wallace, A. T., and Karbassi, P., Germination of oat (Avena byzantina C. Koch) pollen on artificial media, Crop Sci. 8: 506-07, 1868. 